\title{
Determination Of Pyrolysis Kinetics Of Pistachio Shell And Cranberry Seed
}

\author{
Hatice Bayrakçeken*(D, Meltem Kızılca Coruh@ \\ ${ }^{1}$ Department of Chemical Engineering, Atatürk University, Erzurum, Turkey
}

Geliş / Received: 30/01/2020, Kabul / Accepted: 30/08/2020

\begin{abstract}
Pyrolytic degradation behavior of pistachio shell and cranberry seed were investigated by means of thermal analysis techniques such as thermogravimetric (TG) and derivative thermogravimetric (DTG). Pyrolysis study of pistachio shell and cranberry seed, which are the sources of plant biomass, are carried out at four different heating rates $\left(2.5,5,10\right.$ and $\left.20 \mathrm{~K} \mathrm{~min}^{-1}\right)$ in the temperature range of $300-1173 \mathrm{~K}$ in a TGA equipment. The activation energy and pre-exponential factor were determined using different methods as Kissinger-AkahiraSunose (KAS) and Flyn-Wall-Ozawa (FWO). The average activation energies ( $E_{a}$ ) and pre-exponential factor (A) obtained from both models for the pyrolytic degradation behavior of pistachio shell and cranberry seed were found as: $\quad E_{a}=146.5 \mathrm{~kJ} \mathrm{~mol}^{-1}$ and $A=17.99 \mathrm{~min}^{-1}$ for KAS; $E_{a}=159.3 \mathrm{~kJ} \mathrm{~mol}^{-1}$ and $A=34.15 \mathrm{~min}^{-1}$ for FWO and $\quad E_{a}=191.1 \mathrm{~kJ} \mathrm{~mol}^{-1}$ and $A=25.93 \mathrm{~min}^{-1}$ for KAS; $E_{a}=210.7 \mathrm{~kJ} \mathrm{~mol}^{-1}$ and $A=42.63$ $\min ^{-1}$ for FWO, respectively.
\end{abstract}

Keywords: Biomass, Pyrolysis, Thermal analysis, Kinetic parameters

\section{Şam Fıstığı Kabuğu ve Kızılcık Çekirdeğinin Piroliz Kinetiğinin Belirlenmesi}

\section{$\ddot{O} \mathbf{z}$}

Şam fıstığı kabuğu ve kızılcık çekirdeğinin pirolitik bozunma davranışı, termogravimetrik (TG) ve diferansiyel termogravimetrik (DTG) gibi termal analiz teknikleri ile araştırılmıştır. Bitki biyo kütlesinin kaynağı olan şam fıstığı kabuğu ve kızılcık çekirdeğinin piroliz çalışması, dört farklı 1sıtma hızında $\left(2.5,5\right.$, 10 ve $\left.20 \mathrm{~K} \mathrm{~min}^{-1}\right)$ TGA cihazında 300-1173 K sıcaklık aralığında yapılmıştır. Aktivasyon enerjisi ve üstel faktör, Kissinger - Akahira - Sunose (KAS) ve Flyn - Wall - Ozawa (FWO) gibi farklı iki yöntem kullanılarak belirlenmiştir. Şam fıstığı kabuğu ve kızılcık çekirdeğinin pirolitik bozunma davranışı için her iki modelden elde edilen ortalama aktivasyon enerjileri (Ea) ve ön üstel faktör (A) şu şekilde bulunmuştur: KAS için $\mathrm{Ea}=146.5 \mathrm{~kJ} \mathrm{~mol}^{-1}$ ve $\mathrm{A}=17.99 \mathrm{~min}^{-1} ; \mathrm{Ea}=159.3 \mathrm{~kJ} \mathrm{~mol}^{-1}$ ve A min ${ }^{-1}=34.15, \mathrm{FWO}$ ve $\mathrm{Ea}=191.1 \mathrm{~kJ}$ $\mathrm{mol}^{-1}$ ve $\mathrm{A}=25.9 \mathrm{~min}^{-1} 3$; KAS için; $\mathrm{Ea}=210.7 \mathrm{~kJ} \mathrm{~mol}^{-1}$ ve $\mathrm{A}=42.63 \mathrm{~min}^{-1} \mathrm{FWO}$ için.

Anahtar Kelimeler: Biyokütle, Piroliz, Termal analiz, Kinetik parametreler 


\section{Introduction}

In recent years, there are two major problems that have occupied the world agenda. One of them is environmental problems and the other is energy crisis. Some greenhouse gases with the combustion of fossil fuels; gases such as carbon dioxide $\left(\mathrm{CO}_{2}\right)$, methane $\left(\mathrm{CH}_{4}\right)$, nitrous oxide derivatives $\left(\mathrm{NO}_{\mathrm{x}}\right)$, ozone $\left(\mathrm{O}_{3}\right)$, sulfur oxide derivatives $\left(\mathrm{SO}_{\mathrm{x}}\right)$, and water vapor are released into the environment. The major cause of global warming and climate change is not the limitation of $\mathrm{CO}_{2}$ emissions. The average $\mathrm{CO}_{2}$ emission per capita is 5.4 tons per year. By 2050, $\mathrm{CO}_{2}$ emissions should be reduced to two tons per person. In addition, the idea that the existing fossil fuel resources will not be able to meet future demand leads to a continuous increase in energy prices. [Calkins, 2009; Zhang et. al. 2010]. In the face of this negative situation of fossil resources and obtained fuels, research on finding and using alternative renewable energy sources has accelerated in recent years. Biomass is the most important alternative energy source. Biomass is generally hydrocarbon-containing substances of plant or animal origin and is mostly organic. Depending on the type of biomass, the amount of inorganic material contained may vary. Most biomass sources are plants. Plants take $\mathrm{CO}_{2}$ from the atmosphere and water from the soil. Biomass is formed by converting them into carbohydrates through photosynthesis using sunlight and chlorophyll. One of the biggest advantages of biomass is that it grows everywhere and is inexhaustible. In addition, biomass provides a clean solution to environmental problems and does not interfere with the natural cycle of carbon. Compared to fossil fuels, it is less harmful to the environment. Biomass is converted to solid, liquid and gaseous fuels through various thermochemical processes, as well as by direct combustion changing into to energy of biomass. [Çağlar and Demirbaş,2000; Sharma et. al. 2000; Çağlar and Demirbaş, 2002]. There are three types of biomass conversion technologies including physical, thermochemical and biochemical conversion processes. Thermochemical conversion from biomass is carried out by processes such as carbonization and pyrolysis (Demirbas, 2004; Özçimen and ErsoyMeriçboyu, 2008; Ravindranath, and Hall, 1995)

One of the most widely used conversion processes is pyrolysis. The pyrolysis process is a solid state degradation and its kinetic parameters are determined by thermo analytical methods. The behavior of biomass components during pyrolysis can be examined by using thermogravimetric analysis which can be done under isothermal or nonisothermal conditions and kinetic parameters can be calculated by using different mathematical models from mass loss curves. [Orfao and Martins, 2002; Tonbul and Yurdakoç, 2002]. It is known that the shape of the curve obtained by weight reduction as a result of thermogravimetric analysis is a function of reaction kinetics. Different methods are used to determine kinetic variables using this curve. These methods are grouped as integral methods which use weight change directly with temperature, differential methods using weight change rate, difference differential methods considering second differences in weight change rate and special methods which can be applied to first speeds. The fact that fossil energy sources, which meet most of our energy needs, will be depleted in the near future requires the widespread use of alternative energy sources. Renewable energy sources involve sources such as solar, wind, hydraulic, geothermal, wave and biomass energy. The potential of biomass energy is equivalent to 10 times 
today's global commercial energy use and 200 times food consumption (El Bassam and Dambroth, 2006). Biomass sources store solar energy through photosynthesis. The storage of solar energy with very low intensity is difficult even through sensitive collectors. However, biomass is an important alternative energy source since it stores this energy in its structure. Thus, material should be selected by considering that many countries should use the most appropriate and economical agricultural and forest products as alternative energy sources according to their ecological conditions. Turkey has a strong agricultural potential. There are various agricultural residues, especially food residues (Özçimen and Ersoy-Meriçboyu, 2008; Özçimen and Ersoy-Meriçboyu, 2010). In this study, two different biomass materials were used: pistachio shell and cranberry seed. The reason for the selection of these materials was that they have different structural and chemical properties and also significant potentials in renewable energy sources. In Turkey, the production of pistachio and cranberry is 12.000 tons and 150.000 tons, respectively.

In this study, pyrolytic degradation behavior of cranberry seed and pistachio shell at different heating rates were investigated by Thermogravimetric analysis. KissingerAkahira-Sunose (KAS) (Akahira and Sunose, 1971) and Flyn - Wall - Ozawa (FWO) (Flynn and Wall 1966; Ozowa, 1965) methods were used to calculate the different decomposition steps and kinetic parameters for total reaction from the experimental data obtained.

\section{Material and Methods}

\section{a. Materials}

Pistachio shell and cranberry seed samples were purchased from a local supermarket in
Erzurum, Turkey in September 2018. Peach and cherry seeds were dried at room temperature and then ground to a $250 \mu \mathrm{m}$ particle size for use in experiments. Structural and elemental analyzes of the samples were performed before the thermo analytical measurements. The chemical composition of pistachio shell and cranberry seed has been previously reported (Demiral et al., 2009; Wang et al., 2018)

\section{b. Thermal Analysis}

The thermal experiments were carried out using Netzsch STA 409 PC Luxx apparatus. Correction by reference data was done with an empty crucible at measurement conditions, identical to the sample measurement conditions. About $10 \mathrm{mg}$ of sample was packed in a platinum crucible. Measurements were taken with air atmosphere flowrate of 10 $\mathrm{mL} / \mathrm{min}$ under ambient conditions, at a heating rate of $2.5,5,10$ and $20 \mathrm{~K} / \mathrm{min}$, over the temperature range of $300-1173 \mathrm{~K}$ and repeatable results were obtained. Platinum was used as the reference material. The experimental data obtained on the Netzsch STA 409 PC Luxx equipment were transformed to a MS Excel format file to draw TG-DTA curves and used to analyze the thermal kinetics analysis.

\section{c. Kinetic Analysis}

For solid materials such as isothermal and non-isothermal methods TG-DTA method is consequential for determining decomposition temperature/steps and kinetics parameters. In order to deduce experimental data for isothermal and non-thermal heating procedures various mathematical approaches have been determined. Such methods can be generalized under two categories: modelfitting and model-free methods. Flynn-Wall- 
Ozawa, Kissinger-Akahira-Sunose, and Friedman methods can be examples to model free methods which assume that the reaction rate is a function of temperature at constant conversion. Thus the apparent activation energy is not dependent on the reaction mechanism. On the contrary, model fitting methods, such as Satave, Popescu and master plots methods, can be used to identify multistep reaction models that are appropriate for the description of complex kinetics. Equation (1) can be arranged in various ways to obtain several differential equations based methods of calculating apparent activation energy. As discussed, what is assumed by model free methods is that the reaction rate is only a function of temperature at constant conversion, thus the apparent activation energy is not dependent on the reaction mechanism (Pan et al., 2019; Lima et al., 2016; Trache et al., 2017).

$$
\frac{d \alpha}{f(\alpha)}=\frac{\mathrm{A}}{\beta} \exp \left(-\frac{\mathrm{E}_{\mathrm{a}}}{\mathrm{RT}}\right) d T
$$

In order to determine the kinetic variables from the data obtained as a result of thermogravimetric analysis in this study, Kissinger-Akahira-Sunose (KAS) and FlynWall-Ozawa (FWO) methods, which takes into consideration the integral analysis and is widely used in the determination of kinetic parameters, were used. Heating rates were selected according to the model limitation to achieve the best linearity of the kinetic plots for each kinetic model. These methods yield the variation of the effective activation energy $\mathrm{Ea}$ as a function of the extent of conversion degree, $\alpha$.

In the Flyn-Wall-Ozawa (FWO) method, Eq. (2), is based on the approximation of Doyle, for each conversion degree $(\alpha), \ln \beta$ versus $1 / T$ is plotted. The slope of the line is used to calculate activation energy (Ea) pre- exponential factor (A) is determined from the intercept of linearly fitted regression plots (Dhaundiyal. Et al.,2018; Doyle, 1962).

$\ln (\beta)=\ln \left(\frac{A E_{a}}{g(\alpha) R}\right)-5.331-1.052\left(\frac{E_{a}}{R T}\right)$

In the Kissinger-Akahira-Sunose (KAS), Eq. (3), is based on the approximation of CoatsRedfern method, for each conversion degree $(\alpha)$, the left side of equation versus $1 / T$ is plotted. The slope of the line is used to calculate activation energy (Ea) and preexponential factor (A) is determined from the intercept of linearly fitted regression plots (Trache et al., 2017).

$\ln \left(\frac{\beta}{T^{2}}\right)=\ln \left(\frac{A E_{a}}{R g(\alpha)}\right)-\frac{E_{a}}{R T}$

where $\beta$ is the, heating rate, $A$ is the the preexponential factor, $\mathrm{R}$ is the gas constant and $\mathrm{T}$ is the obsolete temperature and $R$ is the gas constant (Jeguirim and Trouvé, 2009; Kız1lca anad Copur, 2016).

\section{Research Findings}

It is possible to determine the decomposition kinetic constants from the evaluation of mass loss data occurring with increasing temperature from thermal analysis. TG-DTG curves corresponding to experiments carried out at heating rates of $2.5,5,10$ and $20 \mathrm{~K} / \mathrm{min}$ under a following air atmosphere for the decomposition pistachio shell and cherry seed in Figures 1 and 2, respectively. When TGA diagrams were analyzed, it was determined that there were three weight loss zones with different slopes by heating both materials up to $1173 \mathrm{~K}$. In the graphs, the first zone is the step where the substances with high moisture and volatility were decomposed and there was the first mass loss that started at approximately $303 \mathrm{~K}$ and was completed at $363 \mathrm{~K}$. The second region, where weight loss was evident on the TG curve, characterized 
the degradation of hemicellulose and cellulose. This zone started at $523 \mathrm{~K}$ and lasted up to $664 \mathrm{~K}$ for pistachio shell and cranberry seed. The third zone, where a slower weight loss was observed, was determined as the thermal degradation zone of the lignin in the sample. The start and end temperatures of the third zone were found to be $695 \mathrm{~K}$ and 763 $\mathrm{K}$, respectively. In this zone, degradation continued with a gradual decrease in mass loss. However, no significant change was observed in mass loss. After the mass loss became almost constant, only carbon-rich solid product and ash remained from the lignocellulosic structure. Thus, when the temperature ranges at which the pyrolysis of pistachio shell and cranberry seed was performed were analyzed, it was observed that the pyrolysis zones reflected the lignocellulosic structure of the biomass.

It is understood from Figure 1 that pistachio shell and cranberry seed tendency to decay from thermal decomposition graphics and this decomposition occurs in three steps. Three regions were determined in TG curves. It was observed in the TG graphs for both substances that decomposition temperatures shift to higher temperatures as the heating rate increases. In the four heating rates used in the degradation experiments, the temperature at which both materials begin and end depending on these rates shows a difference of approximately $120^{\circ} \mathrm{C}$. At the same heating rates, the decomposition temperatures of cranberry seeds are higher than the decomposition temperature of pistachio shell.

Calculation results of thermal kinetic analysis are given in Figures 3-4 and Table 1. Activation energies of cranberry seeds with higher decomposition temperatures according to KAS and FWO models were also calculated larger than the activation energy of pistachio shell. From the slope of the plot of $\ln \beta$ versus 1000/T (Figs. 3 (a, b) for KAS method and the slope of the plot of $\ln \left(\beta / \mathrm{T}^{2}\right)$ versus $1000 / \mathrm{T}$ (Figs. 4 (a, b) for FWO method between 0.1 and 0.9 values of fraction, the values of activation energy were found. In Tables 1 and 2 , the activation energy, and regression coefficients calculated based on FWO and KAS methods (Eqs. 2 and 3) are presented. During the pyrolysis of pistachio shell and cranberry seed, it was found that a fluctuation occurred in the activation energy by raising the conversion fraction. It was determined that activation energy was changed between 86.70 and $340.20 \mathrm{~kJ} \mathrm{~mol}^{-1}$ between the range of 0.1 0.9 conversion. In the literature there are many studies available showing the activation energy values for various biomass samples such as melon seed shell [Ahmed et. al. 2019], chestnut shell [Özsin and Pütün 2018], pistachio nutshell [Işstan et.al. 2016], tobacco waste [Polat et.al. 2016], duckweed sample [Liu et.al. 2020], and coffee husks [Setter et.al.2020]. The obtained activation energy is between $74-288 \mathrm{~kJ} \mathrm{~mol}^{-1}$. Thus, the activation energy values for pistachio shell and cranberry seed calculated using the two models agree with the literature values. The change in activation energy along with the conversion fraction was associated with the thermal degradation of the components of the biomass, and it was also associated with the thermal degradation of cellulose, hemicellulose and lignin (Demirbas, 2010; Özçimen and Ersoy-Meriçboyu, 2008). It was found that the increases and decreases in activation energy showed that the pyrolysis of the seeds was driven by multiple reaction mechanisms. It was detected that the regression coefficients achieved from kinetic analysis were between 0.9705 and 0.9986 . Based on the application of different kinetic methods to the data obtained, it was determined that the average activation energy 
values calculated by the FWO and KAS methods were 159.30 and $146.50 \mathrm{~kJ} \mathrm{~mol}^{-1}$ for pistachio shell in Table 1 and 210.70 and $191.10 \mathrm{~kJ} \mathrm{~mol}^{-1}$ for cranberry seed in Table 2. Average of pre-exponential factor $(A, \min -$ 1) values obtained by FWO and KAS methods tabulated in Tables 1 and 2 for pistachio shell and cranberry seed were 34.15 and 42.63 for FWO and, 17.99 and 25.93 for KAS methods, respectively, as calculated using Eqs. 2 and 3. Order of the reaction thus the rate of constant determines units of the pre-exponential factor. Such units are reciprocal seconds in a first order reaction. The fact that pre-exponential factor depends on frequency of collisions, the factor is correlated with collision theory and transition state theory. Besides, although the factor is frequently described as temperature independent, there is actually such a dependency because the pre-exponential factor is related to molecular collision that is a function of temperature. Here first-order, parallel and irreversible reactions with varying activation energies are assumed to occur simultaneously and pre-exponential factors change based only on activation energy. Thus pre-exponential factor values calculated for pistachio hull and cranberry stone displayed a similar change with calculated activation energy values (Criado et al., 2005; Jagannadham, 2010). The results demonstrated that the activation energy and pre-exponential values of cranberry seed is higher than the activation energy of pistachio shells.

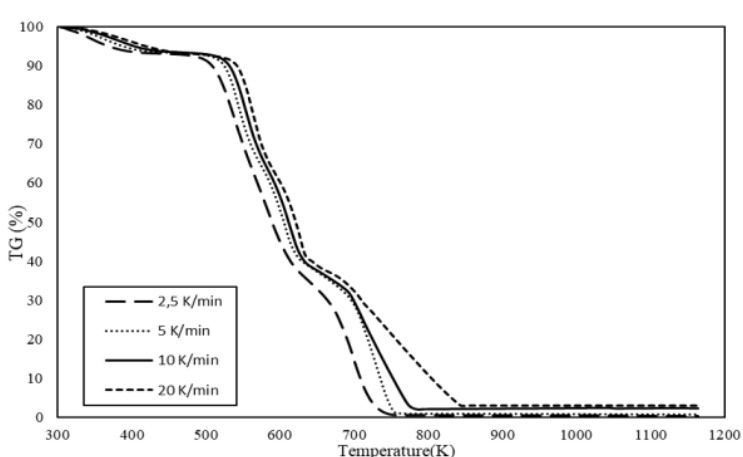

(a)

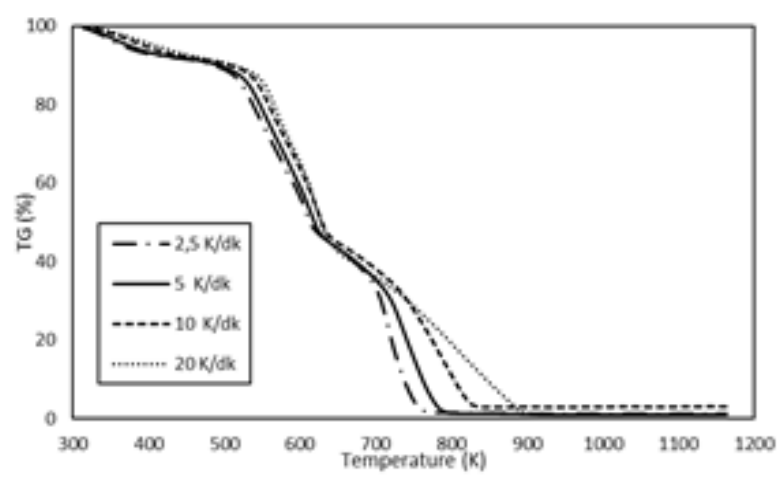

(b)

Figure 1. TG curves of a) pistachio shell b) cranberry seed for different heating rates

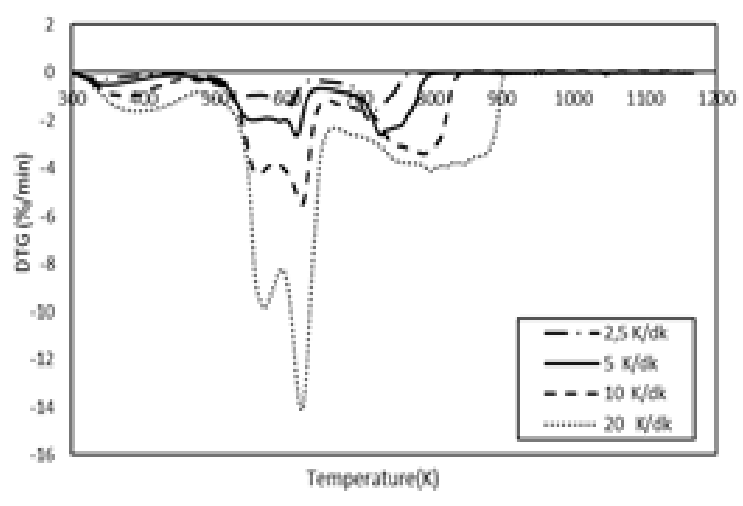

(a)

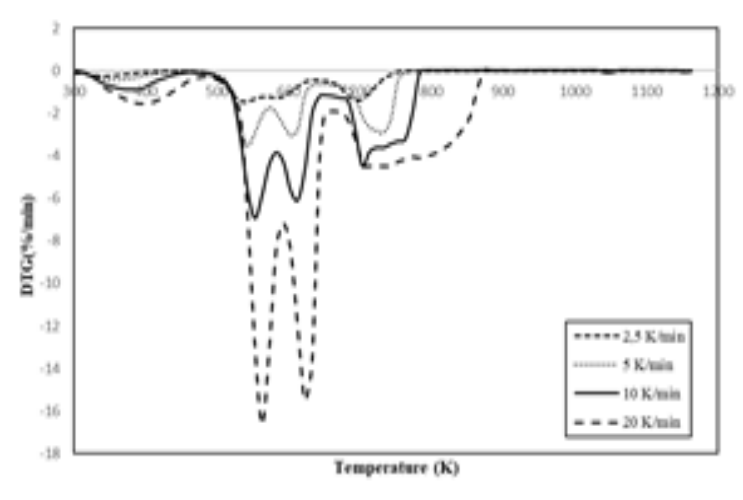

(b) 
Figure 2. DTG curves of $\mathrm{c}$ of a) pistachio shell b) cranberry seed for different heating rates

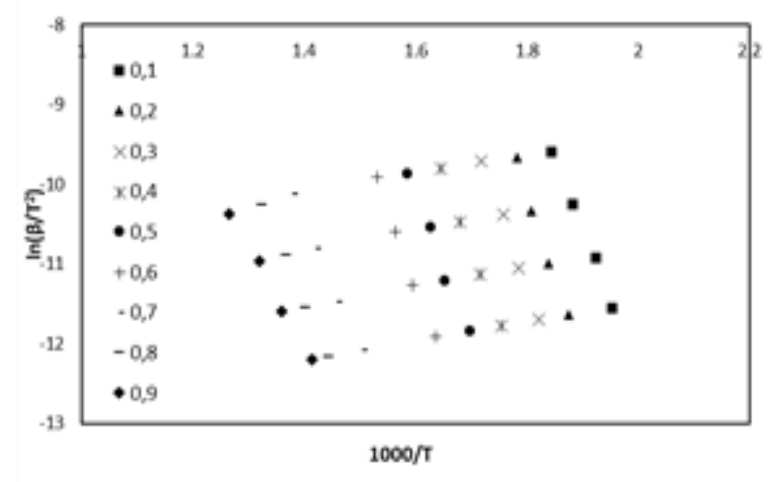

(a)

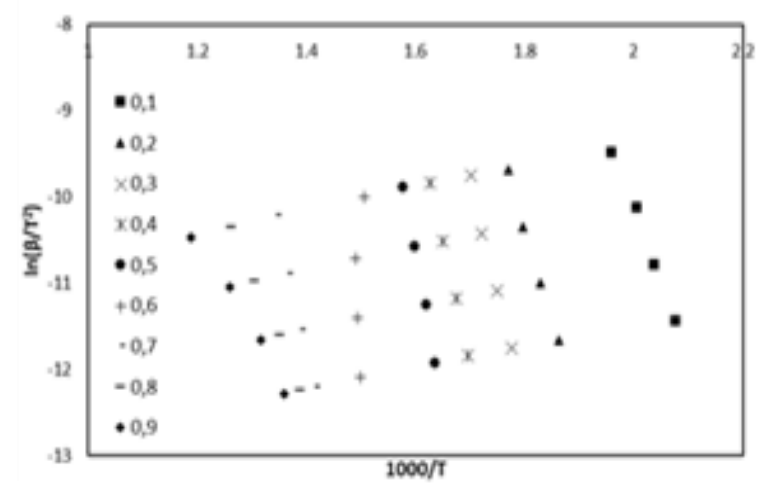

(b)

Figure 3. Decomposition peak temperatures variation with heating rates at given conversion fraction (a) values by the KAS method for the decomposition of a) pistachio shell b) cranberry seed

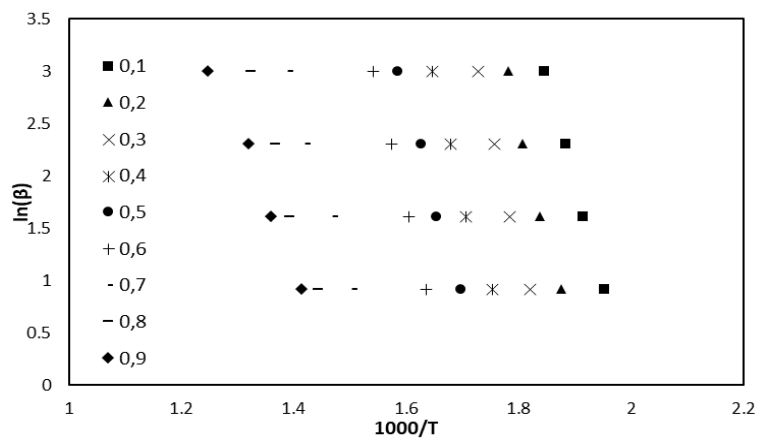

(a)

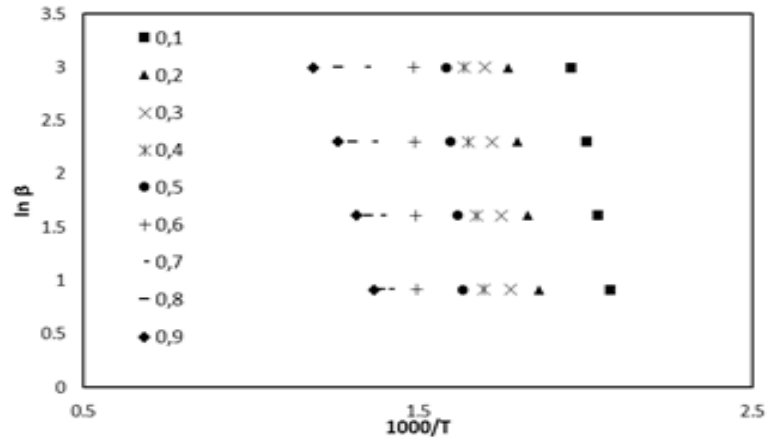

(b)

Figure 4. Decomposition peak temperatures variation with heating rates at given conversion fraction (a) values by the FWO method for the decomposition of a) pistachio shell b) cranberry seed

Table 1. Activation energies and preexponential factor from KAS and FWO methods for the decomposition of a) pistachio shell and b) cranberry seed

\begin{tabular}{|c|c|c|c|c|c|c|}
\hline & \multicolumn{2}{|c|}{ KAS } & \multicolumn{2}{c|}{ FWO } & \\
\hline$\alpha$ & $E_{\mathrm{a}}\left(\mathrm{kJ} \mathrm{mol}^{-1}\right)$ & $\mathrm{R}^{2}$ & $\begin{array}{c}\mathrm{A} \\
\left(\mathrm{min}^{-1}\right)\end{array}$ & $\begin{array}{c}\mathrm{E}_{\mathrm{a}} \\
\left(\mathrm{kJ} \mathrm{mol}^{-1}\right)\end{array}$ & $\mathrm{R}^{2}$ & $\begin{array}{c}\mathrm{A} \\
\left(\mathrm{min}^{-1}\right)\end{array}$ \\
\hline 0.1 & 148.60 & 0.9953 & 23.39 & 161.80 & 0.9986 & 38.91 \\
\hline 0.2 & 175.00 & 0.9915 & 27.77 & 184.10 & 0.9923 & 42.38 \\
\hline 0.3 & 163.80 & 0.9972 & 24.17 & 188.20 & 0.9964 & 42.08 \\
\hline 0.4 & 152.60 & 0.9986 & 20.40 & 162.70 & 0.9848 & 35.16 \\
\hline 0.5 & 147.90 & 0.9909 & 18.30 & 155.80 & 0.9917 & 32.67 \\
\hline 0.6 & 160.90 & 0.9926 & 19.68 & 184.10 & 0.9998 & 37.14 \\
\hline 0.7 & 131.60 & 0.9968 & 11.70 & 145.70 & 0.9936 & 27.32 \\
\hline 0.8 & 133.40 & 0.9973 & 11.01 & 146.70 & 0.9833 & 26.34 \\
\hline 0.9 & 104.40 & 0.9962 & 5.54 & 104.70 & 0.9879 & 25.34 \\
\hline Average & 146,50 & & 17.99 & 159.30 & & 34.15 \\
\hline
\end{tabular}

(a)

\begin{tabular}{|c|c|c|c|c|c|c|}
\hline & \multicolumn{2}{|c|}{ KAS } & \multicolumn{2}{c|}{ FWO } & \\
\hline$\alpha$ & $\begin{array}{c}\mathrm{E}_{\mathrm{a}} \\
\left(\mathrm{kJ} \mathrm{mol}^{-1}\right)\end{array}$ & $\mathrm{R}^{2}$ & $\begin{array}{c}\mathrm{A} \\
\left(\mathrm{min}^{-1}\right)\end{array}$ & $\begin{array}{c}\mathrm{E}_{\mathrm{a}} \\
\left(\mathrm{kJ} \mathrm{mol}^{-1}\right)\end{array}$ & $\mathrm{R}^{2}$ & $\begin{array}{c}\mathrm{A} \\
\left(\mathrm{min}^{-1}\right)\end{array}$ \\
\hline 0,1 & 140.10 & 0.9940 & 23.58 & 148.40 & 0.9947 & 37.99 \\
\hline 0.2 & 176.00 & 0.9953 & 27.74 & 185.10 & 0.9957 & 42.36 \\
\hline 0.3 & 216.30 & 0.9948 & 34.45 & 225.90 & 0.9952 & 49.16 \\
\hline 0.4 & 241.60 & 0.998 & 37.47 & 285.00 & 0.9883 & 59.04 \\
\hline 0.5 & 282.20 & 0.9948 & 43.63 & 340.20 & 0.9922 & 67.81 \\
\hline 0.6 & 223.90 & 0.9950 & 29.24 & 239.90 & 0.9855 & 45.11 \\
\hline 0.7 & 230.00 & 0.9974 & 26.97 & 240.60 & 0.9981 & 41.89 \\
\hline 0.8 & 122.90 & 0.9981 & 8.32 & 135.40 & 0.9985 & 23.58 \\
\hline 0.9 & 86.70 & 0.9825 & 1.99 & 95.60 & 0.9947 & 16.71 \\
\hline Average & 191.10 & & 25.93 & 210.70 & & 42.63 \\
\hline
\end{tabular}

(b)

\section{Conclusions}

Pyrolysis study of pistachio shell and cranberry seed, which are the sources of plant 
biomass, are carried out under air flow rate of $10 \mathrm{ml} \mathrm{min}{ }^{-1}$ and heating rates of 2.5, 5, 10 and $20 \mathrm{~K} / \mathrm{min}$ in the temperature range of 300 $1173 \mathrm{~K}$ by means of thermal analysis techniques (TG/DTG). Three regions were determined in TG curves. (i) Separation of moisture and high volatile components (ii) Breaking of hemicellulose and cellulose (iii) Degradation of lignin at high temperature. Energy values calculated by KAS and FWO methods were found as 146.50 and $159.30 \mathrm{~kJ}$ $\mathrm{mol}^{-1}$ for pistachio shell and 191.10 and $210.70 \mathrm{~kJ} \mathrm{~mol}{ }^{-1}$ for cranberry seed, respectively. As a result of the kinetic analysis, regression coefficients are found to be between 0.9880 and 0.9983 . Also the activation energy values produced by the FWO and KAS methods are found very close. The fact that these figures are close to one displays that the kinetic model that is used is a theoretical model equation that can successfully define pyrolytic degradation. Ea represents the minimum amount of energy required to start the reaction; therefore, if higher Ea values are greater, a reaction will start more difficult, ie the lower the $\mathrm{E}_{\mathrm{a}}$ value, the faster the reaction rate. The low value of Ea indicates that it has an important bioenergy potential to be used in thermochemical conversion processes such as pyrolysis and combustion. According to the model results, it can be said that the pistachio shell can burn more easily than the cranberry seed.

\section{References}

Ahmed, A., Afolabi, E.A.,Garba, M.U., Musa, U., Alhassan, A. and Ishaq, I. (2019). Effect of particle size on thermal decomposition and devolatilization kinetics of melon seed shell, Chemical Engineering Communications, 206, 9, 1228-1240.

Akahira, T. (1971), Sunose Method of Determining Activation Deterioration Constant of Electrical Insulating Materials, Res. Rep. Chiba Inst. Technol. (Sci. Technol.), 16, 22-31.

Çağlar, A., Demirbaş, A. (2000). Conversion of Cotton Cocoon Shell to Liquid Products by Pyrolysis, Energy Conversion and Management, 41, 1749 - 1756.

Çağlar, A., Demirbaş, A. (2002) Hydrogen Rich Gas Mixture from Olive Husk via Pyrolysis, Energy Conversion and Management, 43, 109 - 117.

Calkins, M. (2009). Materials for sustainable sites, John Wiley \& Sons Inc., Hoboken, New Jersey, 14-24.

Criado J. M., Pérez-Maqueda L. A., SánchezJiménez P. E. (2005) Dependence of the preexponential factor on temperature errors in the activation energies calculated by assuming that a is constant. Journal of Thermal Analysis and Calorimetry, 82, 671-675.

Demirbas A. (2004). Combustion characteristics of different biomass fuels, Progress in Energy and Combustion Science, 30 (2), 219-230.

Demiral İ., Gulmezoglu Atılgan N., Sensoz S. 2009 Production Of Biofuel From Soft Shell Of Pistachio (Pistacia Vera L.), Chemical Engineering Communications Chem. Eng. Comm., 196,104-115. 
Dhaundiyal A., Singh S. B., Hanon M. M., Rawat R. (2018). Determination of Kinetic Parameters for the Thermal Decomposition of Parthenium hysterophorus, Environmental and Climate Technologies, 22, 5-21.

Doyle, C.D. (1962). Estimating isothermal life from thermogravimetric data. Journal of Applied Polymer Science, 6, 639-42.

El Bassam N., Dambroth M.(2006). A concept of Energy Plants' Farm, Biomass for Energy, Industry and Environment: 6th E.C. Conference.

Flynn, J.H. Wall, L.A. (1966). General treatment of the thermogravimetry of polymers, J. Res. Nat. Bur. Stand, 70, 487523.

Isitan, S., Ceylan, S., Topcu, Y., Hintz, C., Tefft, J., Chellappa, T., Guo, J., Goldfarb, J. L. (2016). Product quality optimization in an integrated biorefinery: Conversion of pistachio nutshell biomass to biofuels and activated biochars via Pyrolysis, Energy Conversion and Management, 127 576-588.

Jagannadham V. (2010) How Do We Introduce the Arrhenius Pre-Exponential Factor (A) to Graduate Students?, Creative Education, 2, 128-129.

Jeguirim, M., Trouvé, G. (2009). Pyrolysis characteristics and kinetics of Arundo donax using thermogravimetric analysis, Bioresource Technology, 100, 4026-4031.

Kizılca M., Copur M. (2016). Investigation of the Thermal Decomposition Kinetics of Chalcopyrite Ore Concentrate using Thermogravimetric Data, Chemical Engineering Communications, 203, 692-704.
Lima A. C. R., China B. L. F., Jawada Z. A., Hiia K. L. ( 2016 ). Kinetic analysis of rice husk pyrolysis using Kissinger-AkahiraSunose (KAS) method. Procedia Engineering, 148, 1247 - 1251.

Liu, H., Ahmad, M.S., Alhumade, H., Elkamel, A., Sammak, S., Shen, B. (2020). A hybrid kinetic and optimization approach for biomass pyrolysis: The hybrid scheme of the isoconversional methods, DAEM, and a parallelreaction mechanism, Energy Conversion and Management, 208, 112531.

Li X., Liu Y., Hao J., Wang W. (2018). Study of Almond Shell Characteristics, Materials, 11,1782

Orfao,J.M., Martins, F.G. (2002). "Kinetic analysis of thermogravimetric data obtained under linear temperature programming, a method based on calculations of the temperature integral by interpolations", Thermochimica Acta, 390(1-2), 195-211.

Ozawa, T. A. (1965). New Method of Analyzing Thermogravimetric Data, Bull. Chem. Soc. Jpn., 38, 1881-1886.

Özçimen D., Ersoy-Meriçboyu A. (2008). A study on the carbonization of grapeseed and chestnut Shell, Fuel Process Technol, 89, 1041-1046.

Özçimen D., Ersoy-Meriçboyu A. (2010). Characterization of biochar and bio-oil samples obtained from carbonization of various biomass materials, Renewable Energy, 35, 1319-1324.

Özsin, G. and Eren Pütün, A. (2018). Copyrolytic behaviors of biomass and polystyrene: Kinetics, thermodynamics and evolved gas analysis, Korean J. Chem. Eng., $35,2,428-437$. 
Pan N., Li D., Lü W., Dai F. (2019). Kinetic study on the pyrolysis behavior of Jimsar oil shale, Oil Shale, 36, 4, 462-482.

Polat, S., Apaydin-Varol, E. and Eren Pütün, A. (2016). Thermal decomposition behavior of tobacco stem Part II: Kinetic analysis, Energy Sources, Part A: Recovery, Utilization, and Environmental Effects, 38, 20, 3073-3080.

Ravindranath, N.H. Hall, D.O. (1995) Biomass energy, and environment-a developing country perspective from India, Oxford University Press, Oxford.

Setter, C., Silva, F.T.M., Assis, M.R. Ataíde, C.H., Trugilho, P.F., Oliveira, T.J.P (2020). Slow pyrolysis of coffee husk briquettes: Characterization of the solid and liquid fractions, Fuel, 261, 116420.

Sharma R., K., Wooten J. B., Baliga V. L., Lin1 X., Chan W. G., Hajaligol M. R. (2004). Characterization of Chars from Pyrolysis of Lignin, Fuel, 83, 1469-1482.

Tonbul, Y., Yurdakoç, K. (2001). Thermogravimetric Investigation of the Dehydration Kinetics of KSF, K10 and Turkish Bentonite, Turkish Journal of Chemistry, 25, 333-339.

Trache D., Abdelaziz A., Siouani B.(2017). A simple and linear isoconversional method to determine the pre-exponential factors and the mathematical reaction mechanism functions Journal of Therm Analysis and Calorimetry, 128,335-348.

Zhang L., Xu C. (2010). Champagne P., Overview of recent advances in thermochemical conversion of biomass Energy Conversion and Management 51, 969-982. 